\title{
"A Study on Magnum Equity Fund" At SBI Mutual Fund Tirupati
}

\author{
Shaik Mahaboob Basha
}

\begin{abstract}
"Mutual fund is a common pool of money in which investor place their contribution that is to be invested in accordance with the stated objective. The fund belongs to all the investors depending on the proportion of his contribution to the fund."
\end{abstract}

\section{Industry Profile}

The mutual fund industry in India started in 1963 with the formation of Unit Trust of India, at the initiative of the Government of India and Reserve Bank. The history of mutual fund in India can be broadly divided into four distinct phases.

\section{FIRST Phase (19964-87)-UTI all the way}

This phase begin with the inception of the Unit Trust of India (UTI). It remained the only mutual fund player in the country till 1987. UTI started its operations in July 1964 "with a view to encouraging savings and investment and participation in the income, profits and gains accruing the corporation from the acquisition, holding, management and disposal of securities". In short, it was set up by the Indian Government with a view to augments small savings in the country and to channelize these savings to the capital markets. UTI witnessed a slow and steady growth over the 1970s and 1980s and by the end of 1988 it had an Asset under Management (AUM) of Rs.6, 700 crore. It still continues to be the largest player in the domestic mutual fund industry with an AUM of Rs. 23,500 crore as on March 31, 2005.

\section{SECOND Phase (1987-1993)-Enter Public Sector mutual funds}

Public sector mutual funds set up by sector banks, Life Insurance Corporations of Indian (LIC) and the General Insurance Corporation of India (GIC) entered the market in 1987.The first non-UTI Mutual Fund was the SBI Mutual Fund established in June 1987, followed by Can bank Mutual Fund in December 1987, Punjab National Bank in August 1989, India Bank Mutual Fund in November 1989, Bank of India Mutual in June 1990and Bank of Baroda Mutual Fund in October 1992. LIC set up its Mutual Fund in June 1989 while GIC established its mutual fund in December 1990.

During this period, the total assets of the industry grew to about Rs.61028 crore with the total number of schemes increasing to about 167 by the end of 1994 .

\section{THIRD PHASE (1993-2003)-Private players enter the scene}

This phase marked the entry of private sector funds. The phase also signaled the intensification of the competition. Both domestic and foreign players entered the schemes to investors. Kothari pioneer Mutual Fund was the first private sector fund to be established in association with a foreign fund. The opening up of the market to private players saw international players. The total AUM by the end of January 312005 increased to $\$ 34,927$ million from $\$ 23,260$ million in March 1995 with a CAGR of $6.92 \%$.

\section{FOURTH Phase (since February 2004)-UTI' Restructuring and beyond}

In February 2003 the Unit Trust of India Act 1963 was repealed and UTI was bifurcated into two separate entities: Specified Undertaking of the Unit Trust of India, which is still under the Government of India, and the UTI Mutual Fund Ltd. This was done in the wake of the severe payments crisis that UTI suffered on account of its assured return schemes of US-64 that finally resulted in an adverse impact on the Indian capital markets. US-64 was the first scheme launched by UTI with a significant equity exposure and the returns of which were not linked to the market. However, the industry has overcome that shock and is hoped to have learnt its lessons.

\section{Introduction}

\section{Company Profile}

SBI Funds Management is a joint venture between State Bank of India, the country's largest bank and Society General Asset Management (France). A subsidiary of state bank of India, the largest public sector bank in India \& a joint venture with society General asset management with a shareholding ratio of 63:37. One of the 
world's leading fund management companies. With over 20 years of rich experience in fund management, SBI Funds Management Pvt. Ltd. Is one of the largest investment management firms in India managing investment mandates of over 46 lakh investors with a network of over 130 points of acceptance spread across India our vast family of investors is expanding faster and further.

SBI MF draws its strength from India's Largest Bank State Bank of India and Society General Asset Management, France.

\section{MEANING OF RESEARCH}

\section{Research Methodology}

. The advance learner's dictionary of current English lays down the meaning of research as "a careful investigation or inquiry especially through search for new facts in any branch of knowledge."

According to Clifford woody research companies defining and organizing and evaluating data, making deductions and researching conclusions to determine whether they fit the formulating hypothesis.

\section{DATA SOURCES}

The main data sources are the SBI annual reports, the offer documents of mutual fund schemes, and the NAVs and repurchase prices announced by the SBI mutual funds from time to time. Data on market prices are collected from 'The Economic Times', 'Business Line', 'Financial Express', and the 'Monthly Economic Reviews' published by the Centre for Monitoring Indian Economy (CMIE), Mumbai. In addition to this, popular investment periodicals, such as 'Dalal Street', 'Sharekhan', 'Analyst', and 'Capital Market' have been referred. Information was also collected from the various issues of RBI bulletin, 'Currency and Finance'.

No primary data has been collected. However, interviews were conducted with the executives of mutual fund organizations. During the interview, inquiries were made about the status of regulations, current problems of mutual fund industry, and the process of investment decision in SBI mutual funds.

DATA ANALYSIS \& INTERPRETATION COMPARATIVE STUDY TO KNOW PERFORMANCE

Table-1: SBI MAGNUM EQUITY Vs TATA PURE EQUITY

Annual Returns

\begin{tabular}{|c|c|c|c|c|c|c|}
\hline \multirow{2}{*}{ Years } & \multicolumn{3}{|c|}{ SBI Magnum Equity } & \multicolumn{3}{|c|}{ TATA Pure Equity } \\
\hline & Returns & Deviations & Deviations $^{2}$ & Returns & Deviations & Deviations $^{2}$ \\
\hline 2012 & 17.6 & 90.6 & 8208.36 & 17.5 & 126.2 & 15926.44 \\
\hline 2011 & 84.1 & 24.0 & 580.81 & 74.3 & 69.4 & 4816.36 \\
\hline 2010 & -56.3 & 164.5 & 27060.25 & -49.5 & 193.2 & 37326.24 \\
\hline 2009 & 69.5 & 38.7 & 1497.69 & 59.0 & 84.7 & 7174.09 \\
\hline 2008 & -6.7 & 114.9 & 13202.01 & 42.4 & 101.3 & 10261.69 \\
\hline Total & 108.2 & & 50549.12 & 143.47 & & 75504.82 \\
\hline
\end{tabular}

Arithmetic mean

SBI Magnum Equity fund $=\sum \mathrm{x}_{1} / \mathrm{N}$

$=108.2 / 5$

$=21.64 \%$

TATA pure Equity fund $=\sum \mathrm{x}_{2} / \mathrm{N}$

Standard deviation

$$
=143.47 / 5=28.74 \%
$$

SBI Magnum Equity fund $=\sqrt{ } \sum\left(\mathrm{x}_{1}-\mathrm{x}_{1}\right)^{-2} / \mathrm{N}$

$=\sqrt{ } 50549.12 / 5$

$=44.97 \%$

TATA pure Equity fund $\quad=\sqrt{ } \sum\left(\mathrm{x}_{2}-\mathrm{x}_{2}^{-}\right)^{2} / \mathrm{N}$

$=\sqrt{75504.82 / 5}$

$=54.96 \%$

\section{Sharpe Ratio}

$\mathrm{S}_{\mathrm{i}}=\mathrm{R}_{\mathrm{i}}-\mathrm{R}_{\mathrm{f}} / \mathrm{S}_{\mathrm{i}}$

$\mathrm{R}_{\mathrm{i}}=$ Average rate of return

$\mathrm{R}_{\mathrm{f}}=$ Rank free rate of return $=7 \%$

$\mathrm{S}_{\mathrm{i}}=$ Standard déviation

SBI Magnum Equity Fund $=\mathrm{S}_{\mathrm{i}}=21.64-7 / 44.97$

$$
=0.33 \%
$$


TATA pure Equity fund $\quad=\mathrm{Si}=28.74-7 / 54.96$

$=0.40 \%$

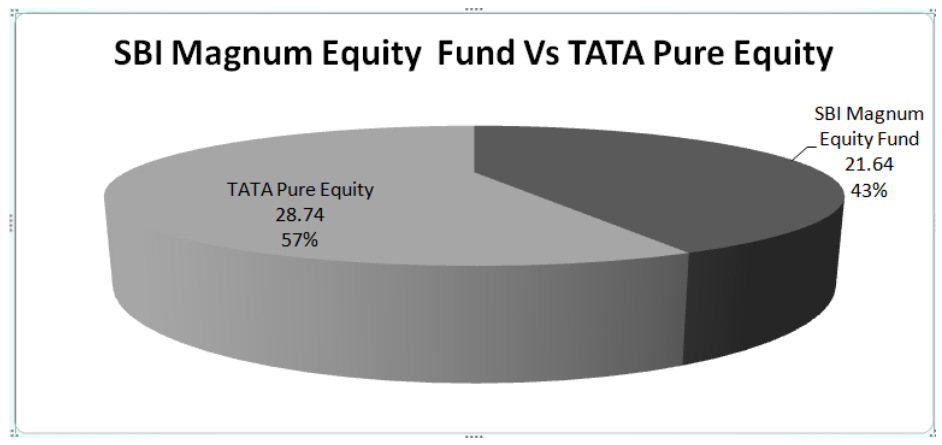

\section{Inference}

Investment in SBI Magnum Equity Fund is low because of Mean (21.64\%) is less than the TATA Pure Equity (28.74\%). But standard deviation of SBI Magnum Equity Fund is less than the TATA Pure Equity. Finally the performance of SBI is low than the TATA Pure Equity.

Table-2: SBI MAGNUM EQUITY Vs UTI MUTUAL FUND

Annual Returns

\begin{tabular}{|c|r|r|r|r|r|r|}
\hline \multirow{2}{*}{ Years } & \multicolumn{3}{|c|}{ SBI Magnum Equity } & \multicolumn{3}{c|}{ TATA Pure Equity } \\
\cline { 2 - 7 } & Returns & \multicolumn{1}{|c|}{ Deviations } & \multicolumn{1}{c|}{ Deviations ${ }^{\mathbf{2}}$} & \multicolumn{1}{c|}{ Returns } & \multicolumn{1}{c|}{ Deviations } & \multicolumn{1}{c|}{ Deviations $^{\mathbf{2}}$} \\
\hline 2012 & 17.6 & 90.6 & 8208.36 & 19.3 & 106.30 & 11299.69 \\
2011 & 84.1 & 24.0 & 580.81 & 82.9 & 42.70 & 1823.29 \\
2010 & -56.3 & 164.5 & 27060.25 & -45.6 & 171.20 & 29309.44 \\
2009 & 69.5 & 38.7 & 1497.69 & 46.1 & 79.50 & 6320.25 \\
2008 & -6.7 & 114.9 & 13202.01 & 22.9 & $102 . .70$ & 10547.29 \\
\hline Total & $\mathbf{1 0 8 . 2}$ & & $\mathbf{5 0 5 4 9 . 1 2}$ & $\mathbf{1 2 5 . 6 0}$ & & $\mathbf{5 9 2 9 9 . 9 6}$ \\
\hline
\end{tabular}

Arithmetic mean

SBI Magnum Equity fund $=\sum \mathrm{x}_{1} / \mathrm{N}$

$$
\begin{aligned}
& =108.2 / 5 \\
& =21.64 \%
\end{aligned}
$$

UTI Mutual fund $=\sum \mathrm{x}_{2} / \mathrm{N}$

$$
\begin{aligned}
& =125.60 / 5 \\
& =25.12 \%
\end{aligned}
$$

\section{Standard deviation}

$$
\begin{aligned}
\text { SBI Magnum Equity fund }= & \sqrt{ } \sum\left(\mathrm{x}_{1}-\mathrm{x}_{1}{ }^{-2}\right) / \mathrm{N} \\
& =\sqrt{50549.12 / 5} \\
& =44.97 \% \\
& =\sqrt{ } \sum\left(\mathrm{x}_{2}-\mathrm{x}_{2}{ }^{-2} / \mathrm{N}\right. \\
\text { UTI Mutual fund } & \sqrt{5} 5299.96 / 5 \\
= & 48.70 \%
\end{aligned}
$$

\section{Sharpe Ratio}

$$
\begin{aligned}
\mathrm{S}_{\mathrm{i}} & =\mathrm{R}_{\mathrm{i}}-\mathrm{R}_{\mathrm{f}} / \mathrm{S}_{\mathrm{i}} \\
\mathrm{R}_{\mathrm{i}} & =\text { Average rate of return } \\
\mathrm{R}_{\mathrm{f}} & =\text { Rank free rate of return }=7 \% \\
\mathrm{~S}_{\mathrm{i}} & =\text { Standard déviation }
\end{aligned}
$$

SBI Magnum Equity Fund $=\mathrm{S}_{\mathrm{i}}=21.64-7 / 44.97$ 


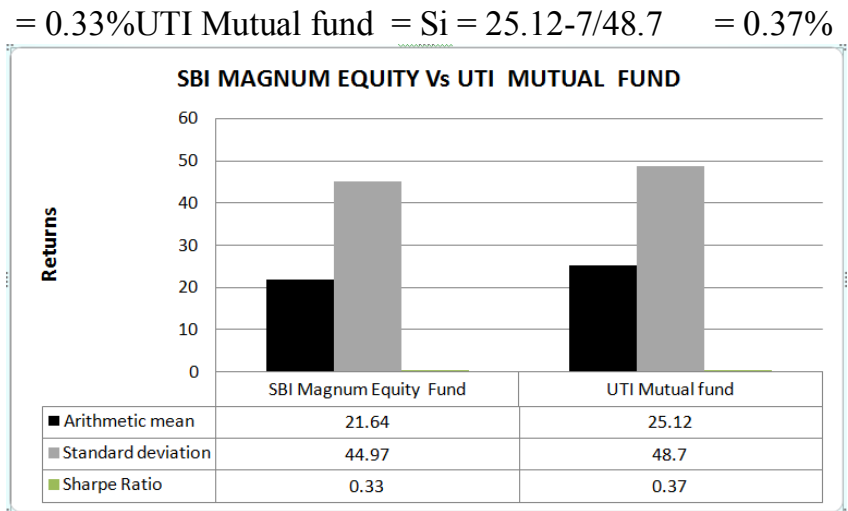

\section{Inference}

Investment in SBI Magnum Equity Fund is better because of mean (21.64\%) is less than the UTI Pure Equity (25.12\%). But standard deviation of SBI Magnum Equity Fund is less than the UTI Pure Equity. Finally the performance of SBI is better than the UTI Pure Equity.

Table-3: SBI Mutual Fund Vs Religare Mutual Fund

Annual Returns

\begin{tabular}{|c|c|c|c|c|c|c|}
\hline \multirow{2}{*}{ Years } & \multicolumn{3}{|c|}{ SBI Magnum Equity } & \multicolumn{3}{|c|}{ Religare Equity Fund } \\
\hline & Returns & Deviations & Deviations $^{2}$ & Returns & Deviations & Deviations $^{2}$ \\
\hline 2012 & 17.6 & 90.6 & 8208.36 & 17.0 & 44.1 & 1944.81 \\
\hline 2011 & 84.1 & 24.0 & 580.81 & 68.3 & -7.2 & 51.84 \\
\hline 2010 & -56.3 & 164.5 & 27060.25 & -49.6 & 110.7 & 12254.49 \\
\hline 2009 & 69.5 & 38.7 & 1497.69 & 25.4 & 35.7 & 1274.49 \\
\hline Total & 114.90 & & 37347.11 & 61.1 & & 15525.63 \\
\hline
\end{tabular}

Arithmetic mean

SBI Magnum Equity fund $=\sum \mathrm{x}_{1} / \mathrm{N}$

$$
\begin{aligned}
& =114.90 / 4 \\
& =28.73 \%
\end{aligned}
$$

Religare Equity Fund $=\sum \mathrm{x}_{2} / \mathrm{N}$

$$
\begin{aligned}
& =61.0 / 4 \\
& =15.28 \%
\end{aligned}
$$

\section{Standard deviation}

SBI Magnum Equity fund $=\sqrt{ } \sum\left(\mathrm{x}_{1}-\mathrm{x}_{1}\right)^{-2} / \mathrm{N}$

$$
\begin{aligned}
& =\sqrt{37347.11 / 4} \\
& =48.31 \%
\end{aligned}
$$

Religare Equity Fund $=\sqrt{ } \sum\left(\mathrm{x}_{2}-\mathrm{x}_{2}^{-}\right)^{2} / \mathrm{N}$

$$
=31.15 \%
$$

\section{Sharpe Ratio}

$$
=\sqrt{15525.63 / 4}
$$

$$
\begin{gathered}
S_{i}=R_{i}-R_{f} / S_{i} \\
R_{i}=\text { Average rate of return } \\
R_{f}=\text { Rank free rate of return }=7 \% \\
S_{i}=\text { Standard deviation }
\end{gathered}
$$

SBI Magnum Equity Fund $\quad=\mathrm{Si}=28.73-7 / 48.31$

$$
=0.45 \%
$$

Religare Equity Fund $=\mathrm{Si}=15.28-7 / 31.15=0.27 \%$ 


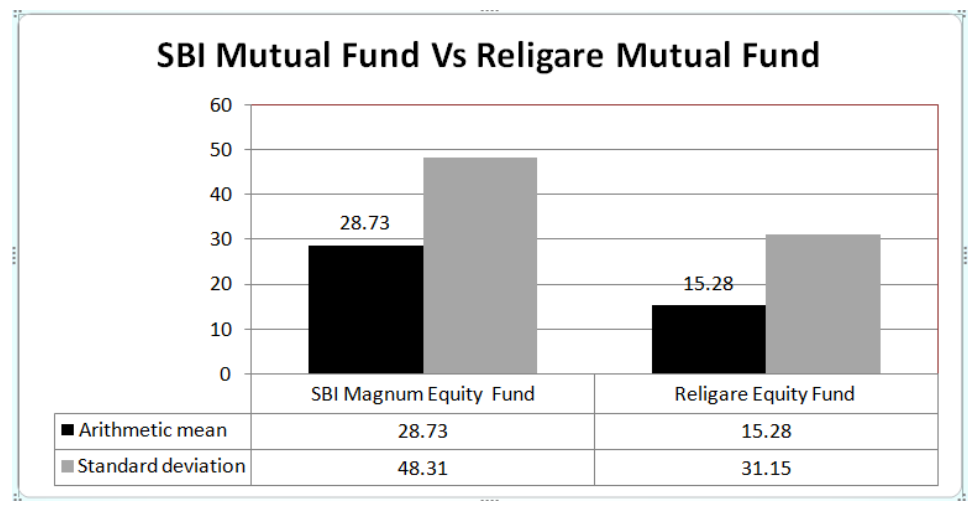

\section{Inference}

Investment in SBI Magnum Equity Fund is better because of mean $(28.73 \%)$ is more than the Religare Equity Fund (15.28\%). But standard deviation of SBI Magnum Equity Fund is less than the Religare Equity Fund. Finally the performance of SBI is also better than the Reliance Equity Fund.

Table-4: Comparison of SBI Magnum Equity fund Returns with other AMCs

$\mathrm{AM}=$ Arithmetic Mean

\begin{tabular}{|c|c|c|c|}
\hline SBI & TATA & UTI & RELIGARE \\
\hline 21.64 & 28.74 & 25.12 & 15.28 \\
\hline
\end{tabular}

\section{RETURNS OF DIFFERENT Amcs}

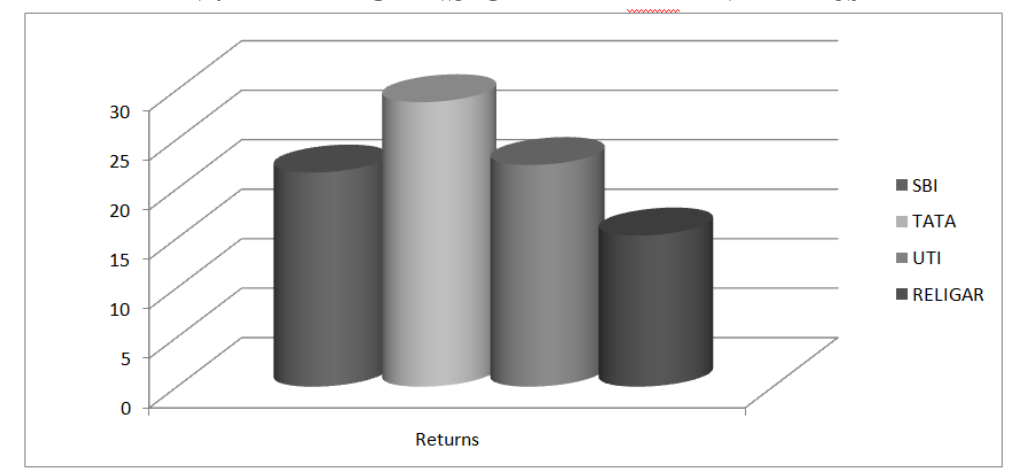

Inference:

Investment in SBI Magnum equity fund has moderate returns when compare to other AMCs.

Table - 5: Comparison of SBI Magnum Equity Fund Risk (SD) with other AMCs

\begin{tabular}{|c|c|c|c|}
\hline SBI & TATA & UTI & RELIGARE \\
\hline 44.97 & 54.96 & 48.70 & 31.15 \\
\hline
\end{tabular}

$\mathrm{SD}=$ STANDARD DEVIATION

RISK OF DIFFERENT AMCs:

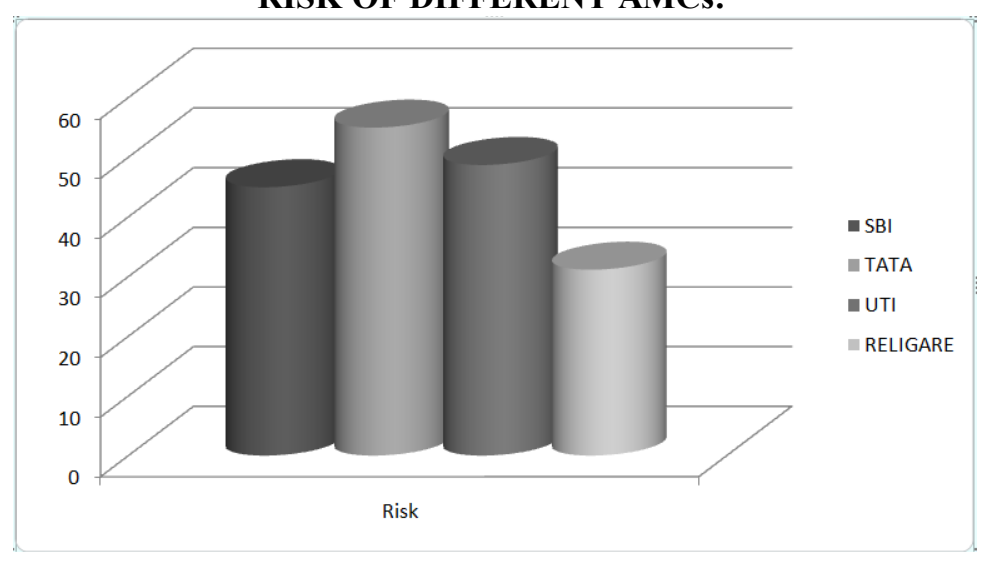


Inference:

Investment in SBI Magnum equity fund has low risk when compare to other AMCs.

Table -6: Comparison of SBI Magnum Equity Fund performance with other AMCs

\begin{tabular}{|c|c|c|c|}
\hline SBI & TATA & UTI & RALIGARE \\
\hline 0.33 & 0.40 & 0.37 & 0.27 \\
\hline
\end{tabular}

PERFORMANCE OF DIFFERENT AMCs:

\section{Inference:}

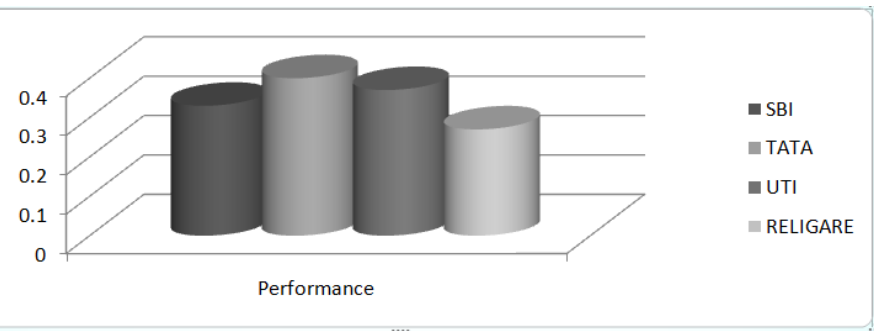

Investment in SBI Magnum equity fund performance is good when compare to other AMCs.

\section{FINDINGS}

- In SBI funds are managing by experienced managers.

- The holdings of stocks are invested in major companies. The total stock holding is around $59.9 \%$

- By calculating arithmetic mean (return) SBI Magnum Equity Fund has moderate returns when compare to other AMCs.

- Based on standard deviation (risk) SBI Magnum Equity Fund has assured low Risk.

- The Sharp ratio (Performance) of SBI Magnum Equity Fund also persist average performance than other AMC's.

- The overall SBI Magnum Equity fund performance is better than the other AMC's.

- SBI Mutual Fund is inferring with low risk (Standard deviation) comparing with other AMC

\section{Conculsion}

From the study it is know that most of the AMCs yield high returns but also have high risk. Usually high risk AMCs are not preferred by risk avoiders. It can be concluded that SBI MAGNUM EQUITY FUND is having good returns, low risk and having average performance over the period of five years.

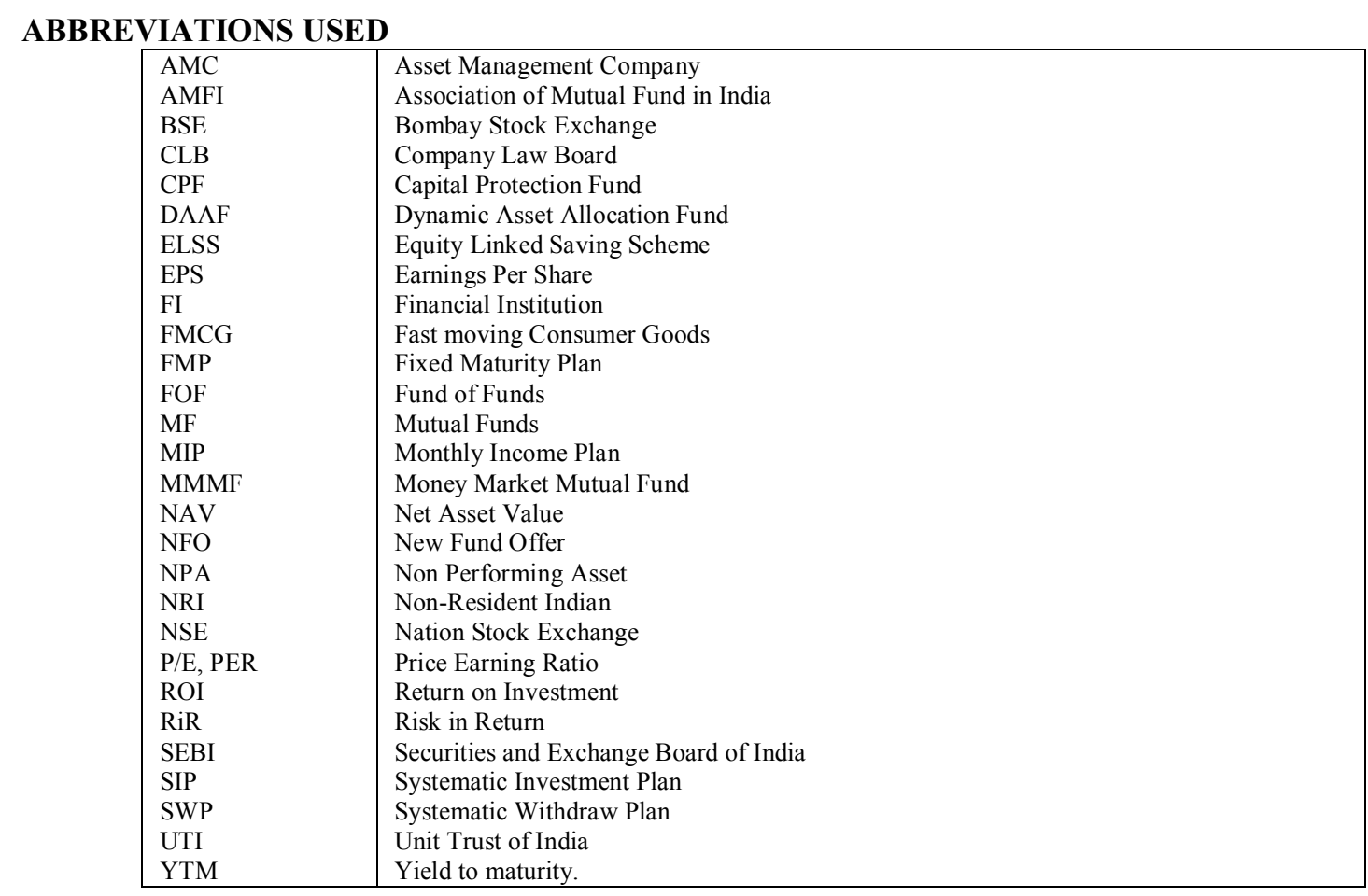


Reference Books

\section{Bibliography}

E. Gordan and K. Natarajan, "Financial Markets and Services", Himalaya Publishing House, 6 ${ }^{\text {th }}$ edition, 2010. Vasant Desai, "Financial Markets and Financial Services", Himalaya Publishing House, 1 st Edition, 2009.

Bharathi. V Pathak, "The Indian Financial System Markets Institutions and Services", Pearson Education, $2^{\text {nd }}$ edition.

\section{Websites}

www.sbimf.com

www.valueresearchonline.com

www.amfi india.com

www.mutualfundindia.com

www.sbifundo.com 